\author{
V.S. Abukenova, A.G. Kaptyonkina* \\ Karagandy University of the name of academician E.A. Buketov, Kazakhstan \\ (*E-mail: alyonakaptyonkina@gmail.com)
}

\title{
Lepidopteran fauna of the city of Karaganda
}

\begin{abstract}
In the article the results of investigation of the species composition of Lepidoptera in city of Karaganda are presented. Studies were conducted in urban parks, squares, courtyards and areas around Karaganda city. Representatives of 11 families, 35 species were identified. The bio indication value of Lepidoptera in monitoring researches is due to their significant role and large biomass in the natural communities, rapid change of the generation, high fecundity and sensitivity to a big number of anthropogenic impact. According to preliminary data, the butterflies of the families Nimphalidae, Satyridae were the most numerous. Background species are Nymphalis urtical L., Melitaea didyma, Hyponephele lycaon Rott. Small and decorating nature species have been identified. In result was made the booklets, which called «Rare and endangered butterflies of the Central Kazakhstan» for the Museum of Nature of E.A. Buketov Karaganda State University. These species must be monitored in the Karaganda city. Refined data on species are pests. Some species are recommended for collecting and training in summer subject schools or at Universities in entomology classes. Further, it is planned to study the distribution of Lepidoptera in the city.
\end{abstract}

Keywords: fauna of the city, Nymphalidae, Satyridae, urban ecosystem, species adorning nature, insects, Lepidoptera, butterflies.

\section{Introduction}

The study of urban fauna is important for the complex assessment of biological diversity, assessment of the current state of faunal complexes and the identification of trends in their future development and variability. The importance of such research is growing in connection with the realization of regional and national sustainable developing programs, as well as global strategies, programs and plans for the conservation and sustainable use of biodiversity.

One of the most important aspects is to study of modern ecological status, especially to the influence of the anthropogenic factor on natural communities [1]. To determine the characteristics of the distribution of fauna in urban ecosystems in different countries, animals of various taxonomic rank are studied.

Lepidoptera are an important part of many terrestrial ecosystems, including urban communities. Representatives of this systematic group have great practical importance for plants, as pollinators. Some species may also be a pest of forestry and agriculture [2]. It is obvious that day butterflies (Lepidoptera) are one of the most noticeable representatives of insects in various natural zones, while many regions of Kazakhstan are not sufficiently studied from an ecological and entomological point of view. The Lepidoptera of Kazakhstan is most studied due to the work of employees of the Institute of Zoology (Almaty city) and Russian specialists [3, 4], but problems remain in identifying the local distribution of species.

It is known that day-flying butterflies - Lepidoptera are a popular object for monitoring the ecological state of the wild. The bio indication value of Lepidoptera in monitoring studies is due to their significant role and large biomass in the natural communities, rapid change of the generation, high fecundity and sensitivity to a big number of anthropogenic impact, and visual visibility [5]. Data on the species composition of Lepidopteran Karaganda have not been published previously. The purpose of this work was to study the species composition and biotopic distribution of Lepidoptera in the city.

\section{Materials and methods}

The object of study were day-flying insects - Lepidoptera. We used materials from field practices of Karaganda state university's students and our own collections of the authors, conducted in the summer of 2019 in the natural environment and in the urban areas of Karaganda. To determine the species, the key anatomical and morphological characters of the group were studied $[6,7]$. Identification was carried out using reference keys $[8,9]$ and relevant manuals [10]. The dates of collection of adults, as well as the occurrence of other stages of development of Lepidoptera were recorded. Butterflies were taken into account on $1 \times 1 \mathrm{~km}$ routes. An approximate transect method was used, modified for monitoring purposes [11]. The total number of routes is 19 , the number of registered butterflies is 625 . 
The study of Lepidoptera was carried out in three sections of the city. Section 1 - the Central Park of the city in Karaganda. Section 2 - the Victory Park (located in the southeast of the city). Section 3 - KSU District (territory adjacent to the Karaganda State University).

\section{Results and discussion}

Observations and gatherings during the growing season made it possible to register the following Lepidoptera families: Arctiidae, Hesperiidae, Pieridae, Lycaenidae, Nimphalidae, Sphingidae, Notodontida, Zygaenidae, Lymantriidae [12].

The summation of data on routes was carried out using phonological tables [13]. Table 1 presents the option of processing data on families and their representatives, the place of their collection, and the registration period.

Table 1

Registration of observations of Lepidoptera in the city

\begin{tabular}{|c|c|c|c|c|c|}
\hline № & Representatives & Observation area & Date and time & Weather & $\begin{array}{l}\text { The num- } \\
\text { ber of } \\
\text { meetings }\end{array}$ \\
\hline 1 & 2 & 3 & 4 & 5 & 6 \\
\hline 1 & $\begin{array}{l}\text { Family Skipper butterfly } \\
\text { (Hesperiidae) } \\
\text { a) Thymelicus lineola O. Adopaea }\end{array}$ & $\begin{array}{c}\text { Karaganda } \\
\text { KSU district (terri- } \\
\text { tory adjacent to } \\
\text { the Karaganda } \\
\text { State University) }\end{array}$ & $\begin{array}{c}4.06 .2017 \\
11: 00-15: 00\end{array}$ & $\begin{array}{l}\text { Fair, } \\
\text { windless } \\
\text { weather } \\
\mathrm{t}=24^{\circ} \mathrm{C}\end{array}$ & 7 \\
\hline 2 & $\begin{array}{l}\text { Family Pieridae } \\
\text { a) Cabbage butterfly (Pieris brassicae L.) } \\
\text { b) Pieris rapae (Pieris rapae L.) } \\
\text { c) Pontia daplidice L. (Sinchloe)) }\end{array}$ & $\begin{array}{l}\text { Karaganda, } \\
\text { KSU district }\end{array}$ & $\begin{array}{c}4.06 .2017 \\
11: 00-15: 00\end{array}$ & $\begin{array}{l}\text { Fair, } \\
\text { windless } \\
\text { weather } \\
\mathrm{t}=24^{\circ} \mathrm{C}\end{array}$ & $\begin{array}{l}1 \\
3 \\
2\end{array}$ \\
\hline 3 & $\begin{array}{l}\text { Family Lycaenidae } \\
\text { a) PolyommatusicarusRott. (Lycaena) } \\
\text { b) HeodesdisparrutilusWern. (Cupido) }\end{array}$ & $\begin{array}{l}\text { Karaganda } \\
\text { KSU district }\end{array}$ & $\begin{array}{c}4.06 .2017 \\
11: 00-15: 00\end{array}$ & $\begin{array}{c}\text { Fair, } \\
\text { windless } \\
\text { weather } \\
\mathrm{t}=24^{\circ} \mathrm{C}\end{array}$ & $\begin{array}{l}2 \\
1\end{array}$ \\
\hline 4 & $\begin{array}{l}\text { Family Nymphalidae } \\
\text { a) Nymphalis io L. (Vanessa) }\end{array}$ & $\begin{array}{l}\text { Karaganda, } \\
\text { KSU district }\end{array}$ & $\begin{array}{c}4.06 .2017 \\
11: 00-15: 00\end{array}$ & $\begin{array}{c}\text { Fair, } \\
\text { windless } \\
\text { weather } \\
\mathrm{t}=24^{\circ} \mathrm{C}\end{array}$ & 1 \\
\hline 5 & $\begin{array}{l}\text { Family Satyridae } \\
\text { a) Lasiommata maera L. (Pararge) } \\
\text { b) Coenonympha amyntas Poda (iphis) }\end{array}$ & $\begin{array}{l}\text { Karaganda } \\
\text { KSU district }\end{array}$ & $\begin{array}{c}5.06 .2017 \\
16: 00-18: 00\end{array}$ & $\begin{array}{c}\text { Clear, } \\
\text { breeze is } \\
\text { gentle, gusty } \\
\text { (after rain) } \\
\mathrm{t}=23^{\circ} \mathrm{C}\end{array}$ & \\
\hline 6 & $\begin{array}{l}\text { Family Hesperiidae } \\
\text { a) Thymelicus lineola O. (Adopaea) }\end{array}$ & $\begin{array}{l}\text { Karaganda, } \\
\text { KSU district }\end{array}$ & $\begin{array}{c}5.06 .2017 \\
16: 00-18: 00\end{array}$ & $\begin{array}{c}\text { Clear, } \\
\text { breeze is } \\
\text { gentle, gusty } \\
\text { (after rain) } \\
\mathrm{t}=23^{\circ} \mathrm{C}\end{array}$ & 8 \\
\hline 7 & $\begin{array}{l}\text { Family Pieridae } \\
\text { a) Pieris rapae L. } \\
\text { b) Pontia daplidice L. (Sinchloe) }\end{array}$ & $\begin{array}{l}\text { Karaganda, } \\
\text { KSU district }\end{array}$ & $\begin{array}{c}5.06 .2017 \\
16: 00-18: 00\end{array}$ & $\begin{array}{c}\text { Clear, } \\
\text { breeze is } \\
\text { gentle, gusty } \\
\text { (after rain) } \\
\mathrm{t}=23^{\circ} \mathrm{C}\end{array}$ & $\begin{array}{l}1 \\
3\end{array}$ \\
\hline 8 & $\begin{array}{l}\text { Family Lycaenidae } \\
\text { a) Lycaena phlaeas } \mathbf{L} \text {. (Chrysophanus, } \\
\text { Cupido) } \\
\text { b) Polyommatus icarus Rott.(Lycaena) }\end{array}$ & $\begin{array}{l}\text { Karaganda, } \\
\text { KSU district }\end{array}$ & $\begin{array}{l}11.06 .2017 \\
9: 00-10: 00 \\
13: 00-14: 00\end{array}$ & $\begin{array}{c}\text { Clear, } \\
\text { breeze is } \\
\text { gentle, gusty } \\
\text { (after rain) } \\
\mathrm{t}=23^{\circ} \mathrm{C}\end{array}$ & $\begin{array}{l}2 \\
5\end{array}$ \\
\hline
\end{tabular}




\begin{tabular}{|c|c|c|c|c|c|}
\hline & & & \multicolumn{3}{|c|}{ Continuation of $\mathrm{Table}$} \\
\hline 1 & 2 & 3 & 4 & 5 & 6 \\
\hline 9 & $\begin{array}{l}\text { Family Pieridae } \\
\text { a) Pieris brassicae L. } \\
\text { b) Pieris rapae L. } \\
\text { c) Pontia daplidice L. (Sinchloe) }\end{array}$ & $\begin{array}{l}\text { Karaganda, } \\
\text { the Central Park }\end{array}$ & $\begin{array}{c}05.07-07.07 \\
2017\end{array}$ & $\begin{array}{c}\text { Fair, } \\
\text { windless } \\
\text { weather } \\
\mathrm{t}=26^{\circ} \mathrm{C}\end{array}$ & $\begin{array}{c}24 \\
17 \\
30 \\
5\end{array}$ \\
\hline 10 & $\begin{array}{l}\text { Family Lycaenidae } \\
\text { a) Polyommatus icarus Rott. (Lycaena) } \\
\text { b) Heodes dispar rutilus Wern. (Cupido) }\end{array}$ & $\begin{array}{l}\text { Karaganda, } \\
\text { the Central Park }\end{array}$ & $\begin{array}{c}\text { 09.07. - } \\
11.07 .2018\end{array}$ & $\begin{array}{l}\text { Fair, } \\
\text { windless } \\
\text { weather } \\
\mathrm{t}=25^{\circ} \mathrm{C}\end{array}$ & $\begin{array}{l}30 \\
10\end{array}$ \\
\hline 11 & $\begin{array}{l}\text { Family Nymphalidae } \\
\text { a) Nymphalis io L. (Vanessa) } \\
\text { b) Red admiral butterfly (Vanessa } \\
\text { atalanta L (Pyrameis) } \\
\text { c) Nymphalis urtical L. (Vanessa) }\end{array}$ & Karaganda city & $\begin{array}{c}4.05 .18 \\
3.07 .18 \\
25.06 .18 \\
11.06 .18\end{array}$ & $\begin{array}{c}\text { Fair, } \\
\text { windless } \\
\text { weather } \\
\mathrm{t}=22-25^{\circ} \mathrm{C}\end{array}$ & $\begin{array}{c}5 \\
12 \\
3 \\
7\end{array}$ \\
\hline 12 & $\begin{array}{l}\text { Family Nymphalis antiopa L. (Vanessa)) } \\
\text { a) Polygonia vau-album Schiff. (L-album } \\
\text { Esp.) } \\
\text { b) Voloria euphrosyne L. (Brenthis) }\end{array}$ & Karaganda city & 20.04 .18 & $\begin{array}{l}\text { Fair, } \\
\text { windless } \\
\text { weather } \\
\mathrm{t}=15^{\circ} \mathrm{C}\end{array}$ & $\begin{array}{c}7 \\
11 \\
2\end{array}$ \\
\hline 13 & $\begin{array}{l}\text { Family Satyridae } \\
\text { b) Melanargia galathea L. } \\
\text { c)Hermit (Chazara briseis) } \\
\text { d) Hyponephele jurtina L. (janira L.) } \\
\text { e) Hyponephele lycaon Rott. } \\
\text { f) Lasiommata maera L. (Pararge) }\end{array}$ & Karaganda city & $\begin{array}{l}20.07 .19 \\
20.07 .19 \\
20.07 .19 \\
20.07 .19 \\
20.07 .19\end{array}$ & $\begin{array}{l}\text { Fair, } \\
\text { windless } \\
\text { weather } \\
\mathrm{t}=25^{\circ} \mathrm{C}\end{array}$ & $\begin{array}{c}15 \\
10 \\
6 \\
7\end{array}$ \\
\hline 14 & $\begin{array}{l}\text { Family Arctiidae } \\
\text { a) Arctia caja L. }\end{array}$ & Karaganda city & $\begin{array}{l}28.05 .19 \\
15.07 .19\end{array}$ & & $\begin{array}{l}8 \\
5\end{array}$ \\
\hline 15 & $\begin{array}{l}\text { Family Sphingidae } \\
\text { a) Hyles euphorbiae } \\
\text { b) Deilephila porcellus } \\
\text { c) Macroglos sumstellatarum }\end{array}$ & Karaganda city & $\begin{array}{l}29.07 .19 \\
22.07 .19 \\
15.10 .19\end{array}$ & & $\begin{array}{l}1 \\
1 \\
3\end{array}$ \\
\hline
\end{tabular}

The observations showed that the abundance of species of the family Pieridae accounts for $31.3 \%$ of the total number of Lepidoptera we collected. Species of the Nimphalidae family are also numerous (29.8 \% of all recorded). The Lycaenidae family and the Satyridae family include $15.9 \%$ and $15.6 \%$ of urban dayflying butterflies. The species of the families Arctiidae, Sphingidae, Hesperiidae, Papilionidae, Notodontidae, Lymantriidae, Zygaenidae, respectively, their share is $3.9 \% ; 1.4 \% ; 1.4 \% ; 0.3 \% ; 0.2 \% ; 0.1$ Lepidoptera urban coenosis. For Lymantriinae and Zygaenidae, the data need to be clarified. The diagram (Fig. 1) is compiled according to the percentage of the abundance of species of the family of Lepidoptera in the examined areas of the city.

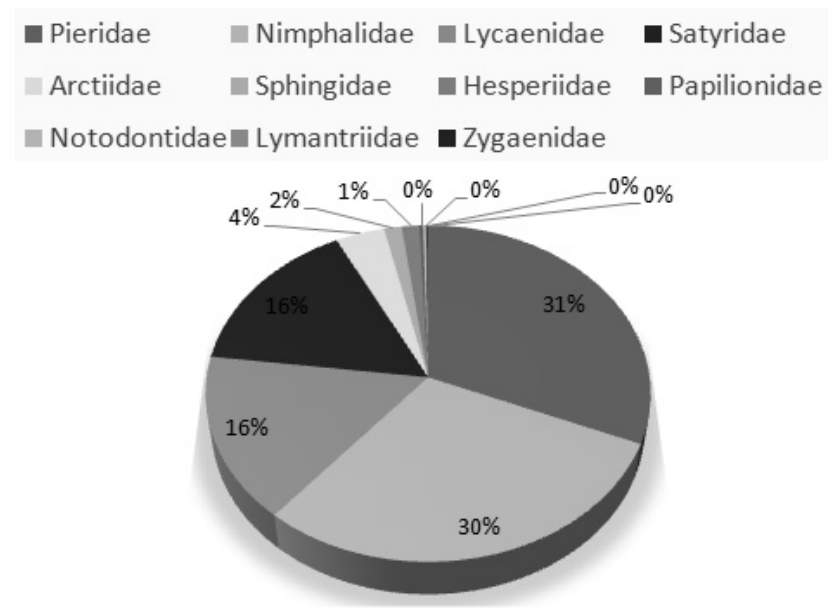

Figure 1. The ratio of the abundance of species of Lepidoptera families in the studied areas of the city of Karaganda 
The Pieridae family includes large or medium sized butterflies, white, yellow or orange, with normally developed legs. In the steppe cenoses of the region, the genera Aporia Hb., Pieris Schrank, Anthocharis L., Colias F., Leptidia Billb. The main representatives of this family are Aporia crataegi L.; Pieris brassicae L.; Pieris napi L.; Pieris rapae L.; Colia serate Esp. There usually meet around 70-76 individuals per one transect.

Caterpillars of Aporia crataegimainly damage fruit trees: apple, pear, plum, apricot, as well as hawthorn and some other hardwoods. In the research area, it is usual, even dominates among the occurring whites. The species Colias hiale L. is distinguished by pronounced sexual dimorphism: the male is lemon yellow, the female is yellowish white. Fore wings with black, hind wings with orange spot in the middle; black border of the front wings with bright spots. It is a widespread and common butterfly.

Butterflies of the Nymphalidae family are also characterized by frequent occurrence on route transects (43-48 specimens), which can be associated with a variety of food preferences of the species. Nymphalids feed on nectar of flowers, sugary juice of damaged trees or fruits, and sometimes even liquid manure and other strongly smelling substances. The most noticeable are hives, drafts, parsley and mother of pearl. In parks and lawns of the city, common urticaria Aglais urticae (Linnaeus, 1758) is a large or medium sized butterfly. Caterpillars live on nettles: blackish, more or less covered with yellow-green stripes. In all areas of observation, urticaria fly singly and in pairs [14].

Neptis rivularis Sc. (Lucilla Den. Et. Schiff) is recorded in May-July. Caterpillars live on meadowsweet, honeysuckle and anemone.

Vanessa cardui L. (Pyrameis) has front wings red, their apical half black with white spots; hind wings somewhat darker with black spots. In May 2019, mass reproduction of the species was noted, especially on flowering shrubs, whereas in other years the butterfly was rare. During the phased flowering of lilac bushes there was a flight of flocks of butterflies from the city to the suburbs [15].

Nymphalis io L. (Vanessa) is a beautiful large butterfly. Caterpillars are black, with frequent white dots and black spikes; they live on nettles, hops, blackberries, raspberries. The butterfly itself prefers to eat on the Cirsium flowers. In the city, mainly single individuals were observed; the abundance was low everywhere.

Admiral butterfly (Vanessa atalanta L. (Pyrameis) is a large bright butterfly. After wintering, it can fly out in April during the warm spring. It met usual in July in the city center [16].

The most common and widespread species of the Lycaenidae family is Polyommatus icarus Rott. (Lycaena). The male is blue above (somewhat lilac), and the female is dark brown, with a blue coating at the wing root and red marginal holes. The view is common for highways, vacant lots, gardens, parks, urban areas. Caterpillar feed plants: Astragalus sp., Coronilla varia, Fragaria vesca, Fragaria sp., Medicago sp., Melilotus sp., Onobrychis sp., Trifolium pratense.

From the second decade of July to the end of August it was noticed in the study area. Butterflies eat on different flowers, prefer Scabiosa ochroleuca, and often sit on the ground. Caterpillars feed plant - cereals from genus Festuca, Stipa, Poa, Sesleria.

Maniola jurtina (Linnaeus, 1758) is widespread. The species is common for the cultural landscape in areas with ruderal vegetation, in pastures. Summer from late June to early August. Forage plants of caterpillars are cereals from genus Roa, Bromus, Festuca, Brachipodium, Milium, Lolium, Alopecurus, Anthoxanthum, and etc.

In the city, closer to the country house, it is possible to observe the large-eyed small-Hyponephele lycaon (Rottemburg, 1775). Caterpillars live on bluegrass and other cereals. The number of marigolds on the transect is $30-36$ individuals.

Papilio machaon L. is a butterfly of the family Papilionidae, is protected in many European countries. The species was registered by the authors within the city, but gravitates to suburban areas and gardens. Caterpillars of butterflies are found on flowering umbrellas - dill, carrots.

Hesperia comma (Linnaeus, 1758) is a species of the Hesperiidae family. Butterflies fly from mid-July to mid-August. Adult nutrition is noted on the flowers of Trifolium, Prunella, Solidago dahurica. Caterpillar fodder plants are Coronilla varia, Elytrigia sp., Festuca sp., Holcus sp., Lotus sp, Poa sp. The species disappears with continuous mowing, overgrazing, and strong trampling of meadows. It is included in the Red Books of a number of European countries (2-4 category) [17]. The study area was a common species with moderate occurrence in dry areas along the outskirts of the city.

Arctia caja L. from the Arctiidae family lives in gardens, urban wastelands and other open places. The feed plant of caterpillars is a variety of undersized plants (like plantain and dandelion). Shaggy caterpillars 
with light shaggy warts. Butterflies fly in July and August, often can be caught in the light. The area is ubiquitous. The number of individuals in some years is high with an abundance of plantain and dandelion.

From Sphingidae family, the wide spreads is the Hyles euphorbiae, flies in May and June and is seen in various garden flowers and in various species of Euphorbia. Rare species in the city on flowering plants is Macroglossum stellatarum. The species is capable of long-distance migrations; we have it from the beginning of May to the end of October and, possibly, represent two migrating generations. Caterpillars develop on bedstands and sprockets.

Thus, during the observation period, 625 Lepidopteran specimens belonging to 35 species and 11 families were registered in the landscape gardening zone of the city. All identified species are representatives of the European-Siberian fauna. Background species belong to the families of Pieridae (5 genera, 7 species) and Satyridae (6 genera, 6 species). According to preliminary data, they need protection: Hesperia comma and a Papilio machaon (as species listed in the Red Books of European states and neighboring countries).

\section{Conclusion}

The study is showed, that allegedly vulnerable native species of Machaon Linnaeus, Parnassius apollo, Iphiclide spodalirie), Laothoe populi Linnaeus, Smerinthus ocellatus, Zegherée ante zheris, Arctia caja Linnaeus compiled information booklets «Rare and endangered butterflies of the Central Kazakhstan» to familiarize schoolchildren, students and other visitors to the Museum of Nature of Karaganda State University. Dangerous pests at the caterpillar stage include almost all types of Pieridae family: Aporia hippie, Pieris brassicae, Pieris rapae, Pieris napi.

Almost all butterflies are pollinators of plants, wild-growing and cultivated, provide seed sets for many species; occupy a certain ecological niche. This is one of the most important values of their stay in urban ecosystems. Many butterflies are quite beautiful, and the aesthetic perception of the world around people is important, especially when relaxing in gardens, parks, squares and boulevards.

The following types of city Lepidoptera possess the best aesthetic features: Lycaenidae Polyommatus icarus (Lycaena), Nympha lisio (Vanessa), red admiral butterfly (Vanessa atalanta (Pyrameis), Nympha lisurtical (Vanessa), Melitaea didyma, Argynnis pandora, Neptis rivularis, Nymphalis antiopa (Vanessa), Polygonia vau-album (L-album Esp.), Melanargia russiae (Suwarovius Hbc.), Melanargia galathea, Chazara briseis, (Hyponenphele jurtina (janira L.), Hyponephele ly caon), Lasiommata maera (Pararge), Arctia caja, Deilephila porcellus, Macroglossum stellatarum, Hyles euphorbiae, white harpy Cerura ermine [18].

One of the results of many years of work by specialists of the Department of Zoology in KSU is to study the species diversity of butterflies in Karaganda was the site butterflies.kz - Butterflies [17], which contains partial materials about the lepidopteran region. Further work is required for a comparative study of the biotopic distribution of Lepidoptera and changes in the fauna during urban processes.

\section{References}

1 Жданко А.Б. Бабочки: Нимфалиды и Сатириды (тип Членистоногие, класс Насекомые). Сер. Животные Казахстана в фотографиях / А.Б. Жданко, В.Л. Казенас. - Алматы: Нур-принт, 2013. — 160 с.

2 Беляев Е.А. Булавоусые чешуекрылые (Lepidoptera: Rhopalocera) междуречья Рязановки и Гладкой (Приморский край, Хасанский район) / Е.А. Беляев, В.В. Дубатолов // Чтения памяти А.И. Куренцова. — 1997. — Вып. 7. — С. 73-100.

3 Бондаренко А.В. Булавоусые чешуекрылые (Lepidoptera: Rhopalocera) ядра трансферной территории «Алтай» / А.В. Бондаренко // Зоологич. журн. - 2009. - Т. 88, № 6. - С. 672-684.

4 Морган С. Бабочки. Всемирная иллюстрированная энциклопедия / С. Морган. - М.: Эксмо, 2014. - 256 с.

5 Кабак Л.В. Бабочки мира / Л.В. Кабак, А.В. Сочивко. - М.: Аванта+, 2001. — 184 с.

6 Татаринов А.Г. Видовое разнообразие булавоусых чешуекрылых на европейском Северо-Востоке России / А.Г. Татаринов, М.М. Долгин. - СПб.: Наука, 2001. — 244 с.

7 Управление природных ресурсов и регулирование природопользования Восточно-Казахстанской области. [Электронный ресурc]. — URL: http://www.e-priroda.gov.kz/index.php/ru/.

8 Карамышева 3.В. Граница между степной и пустынной областями в Центральном Казахстане / 3.В. Карамышева, Е.М. Лавренко, Е.И. Рачковская // Ботан. журн. — 1969. — Т. 54, № 4. — С. 513-527.

9 Карамышева 3.В. Ботаническая география степной части Центрального Казахстана / 3.В. Карамышева, Е.И. Рачковская. - Л.: Наука, 1973. - 278 с.

10 Сайт журнала «Растительный и животный мир Казахстана» [Электронный ресурc]. - URL: https://moxnpn.ru/kazakhstan/68-rastitelnyj-i-zhivotnyj-mir-kazaxstana.html. 
11 Хлус К.Н. Фауна Чешуекрылых урбоэкосистемы г. Черновцы (Украина) / К.Н. Хлус, Л.Н. Хлус // Экологический мониторинг и биоразнообразие. — 2016. — № 1(11). — С. 140-143.

12 Сущев Д.В. Дневные Чешуекрылые на урбанизированной территории / Д.В. Сущев // Изв. ТРТУ. — 2004. — № 1. C. $220-222$.

13 Агроклиматические ресурсы Карагандинской области Казахской ССР. — Л.: Гидрометиздат, 1976. — 114 с.

14 Жакатаева Б.Т. Атмосферные загрязнения г. Караганды / Б.Т. Жакатаева, З.П. Журавлева // Вестн. Караганд. ун-та. Сер. Биология. Медицина. География. — 2010. — № 3(59). — С. 79-84.

15 Бабочки. [Электронный ресурc]. — URL: butterflies.kz

16 Андреев А.В. Оценка биоразнообразия, мониторинг и экосети / А.В. Андреев. - Кишинев: ВІОТІСА, 2002. — 168 с.

17 Павловский Е.Н. Методы ручного анатомирования насекомых / Е.Н. Павловский. — М.: Изд-во АН СССР, 1957. $86 \mathrm{c}$.

18 Чайнери М. Бабочки / М. Чайнери. - М.: Астрель, 2002. - 256 с.

\title{
В.С. Абукенова, А.Г. Каптёнкина
}

\section{Қарағанды қаласының лепидоптер фаунасы}

\begin{abstract}
Мақалада Қарағанды қаласының лепидоптер түрінің құрамын зерттеу нәтижелері келтірілген. Зерттеу қалалық саябақтар, алаңдар, аулалар және Қарағанды қаласының іргелес аумақтарында жүргізілген. 11 тұқымдастық өкілдері, 35 түр анықталды. Лепидоптер қоршаған ортаның экологиялық жағдайын бақылаудың танымал объектісі екені белгілі. Мониторингтік зерттеулердегі лепидоптердің биоиндикациялық мәні олардың табиғи қауымдастықтардағы маңызды рөлі мен үлкен биомассаға, ұрпақтарының тез өзгеруіне, жоғары ұрықтылығына, антропогендік әсердің бірқатар түрлеріне, сезімталдыққа және көрнекілікке байланысты. Қарағанды лепидоптерінің түрлік құрамы туралы мәліметтер бұрын жарияланған жоқ. Алдын-ала мәліметтер бойынша Nymphalidae және Satyridae тұқымдастарының көбелегі ең көп болды. Фондық түрлері - Nymphalis uritative L. (Baнecca), Melitaea didyma Esp., Hyponephele lycaon Rott. Саны аз және табиғатты әсемдеуші түрлері анықталған. Академик Е.А. Бөкетов атындағы Қарағанды университетінің Табиғат мұражайы қала аумағындағы санын мониторингтік бақылау үшін көбелектің түрлері туралы (Орталық Қазақстанның сирек кездесетін және жойылып бара жатқан көбелектері) ақпараттық буклет құрастырды. Зиянкес түрлері бойынша мәліметтер нақтыланған. Кейбір түрлерін жазғы пәндік мектептерде энтомология сабақтарында жинауға және оқуға ұсынылған. Болашақта лепидоптердің қала аумағы бойынша таралуын зерттеу жоспарлануда.
\end{abstract}

Кілm сөздер: қала фаунасы, күндізгі лепидоптер, Nymphalidae, Satyridae, табиғатты безендіретін түрлері, қалалық экожүйе, көбелектер, Lepidoptera.

\section{В.С. Абукенова, А.Г. Каптёнкина}

\section{Фауна чешуекрылых города Караганды}

В статье представлены результаты исследования видового состава чешуекрылых города Караганды. Исследования проводились на территории городских парков, в скверах, дворах и прилегающих территориях г. Караганды. Определены представители 11 семейств, 35 видов. Известно, что булавоусые чешуекрылые являются популярным объектом для мониторинга экологического состояния среды. Биоиндикационное значение чешуекрылых в мониторинговых исследованиях обусловлено их значительной ролью и большой биомассой в природных сообществах, быстрой сменой поколений, высокой плодовитостью, чувствительностью к ряду видов антропогенного воздействия, визуальной заметностью. Данные о видовом составе чешуекрылых Караганды ранее не были опубликованы. По предварительным данным наиболее многочисленными были бабочки семейств Нимфалиды (Nimphalidae) и Бархатницы (Satyrinae). Фоновыми являются виды Крапивница (Nymphalis urtical L. (Vanessa)), Шашечница (Melitaea didyma Esp.), Ликаон (Hyponephele lycaon Rott.). Определены малочисленные и украшающие природу виды. Для Музея природы Карагандинского университета им. академика Е.А. Букетова составлены информационные буклеты о видах («Редкие и исчезающие бабочки Центрального Казахстана»), нуждающихся в мониторинге численности на территории города. Часть видов рекомендована для коллекционирования и обучения в летних предметных школах на занятиях по энтомологии. В дальнейшем планируется изучение распределения чешуекрылых по территории города.

Ключевые слова: фауна города, дневные чешуекрылые, Nymphalidae, Satyridae, украшающие природу виды, урбоэкосистема, бабочки, Lepidoptera. 


\section{References}

1 Zhdanko, A.B., \& Cazenas, V.L., (2013). Babochki: Nimfalidy i Satiridy (tip Chlenistonohie, klass Nasekomye). Seriia Zhivotnye Kazakhstana v fotohrafiiakh. [Butterflies: Nymphalidae and Satyrides (type Arthropods, class Insecta). Series Animals of Kazakhstan in photographs]. Almaty: Nur-print [in Russian].

2 Belyaev, E.A., \& Dubatolov, V.V. (1997). Bulavousye cheshuekrylye (Lepidoptera: Rhopalocera) mezhdurechiia Riazanovki i Hladkoi (Primorskii krai, Khasanskii raion) [Lepidoptera mace (Lepidoptera: Rhopalocera) between the speech of Ryazanovka and Gladka (Primorsky Territory, Khasansky District)]. Chteniia pamiati A.I. Kurentsova - Readings in memory of A.I. Kurentsov, 7, 73-100 [in Russian].

3 Bondarenko, A.V. (2009). Bulavousye cheshuekrylye (Lepidoptera: Rhopalocera) yadra transfernoi territorii «Altai» [Lepidoptera (Lepidoptera: Rhopalocera) nuclei of the Altai transfer territory]. Zoolohicheskii zhurnal — Zoological journal, 6, 672-684 [in Russian].

4 Morgan, S. (2014). Babochki. Vsemirnaia illiustrirovannaia entsiklopediia [Butterflies. World Illustrated Encyclopedia.] Moscow: Exmo [in Russian].

5 Kabak, L.V., \& Sochivko, A.V. (2001). Babochki mira [Butterflies of the World]. Moscow: Avanta+ [in Russian].

6 Tatarinov, A.G., \& Dolgin, M.M. (2001). Vidovoe raznoobrazie bulavousykh cheshuekrylykh na evropeiskom Severo-Vostoke Rossii [Species diversity of club-headed Lepidoptera in the European Northeast of Russia]. Saint Petersburg: Nauka [in Russian].

7 Upravlenie prirodnykh resursov i rehulirovanie prirodopolzovaniia Vostochno-Kazakhstanskoi oblasti [Management of natural resources and environmental management of the East Kazakhstan region]. e-priroda.gov.kz. Retrieved from http://www.epriroda.gov.kz/index.php/ru [in Russian].

8 Karamysheva, Z.V., Lavrenko, E.M., \& Rachkovskaya, E.I. (1969). Hranitsa mezhdu stepnoi i pustynnoi oblastiami v Tsentralnom Kazakhstane [The border between the steppe and desert regions in the Central Kazakhstan]. Botanicheskii zhurnal Botanical Journal, 54 (4), 513-527 [in Russian].

9 Karamysheva, Z.V., \& Rachkovskaya, E.I. (1973). Botanicheskaia heohrafiia stepnoi chasti Tsentralnoho Kazakhstana [Botanical geography of the steppe part of the Central Kazakhstan]. Leningrad: Nauka [in Russian].

10 Sait zhurnala «Rastitelnyi i zhivotnyi mir Kazakhstana» [Site of journal «Flora and fauna of Kazakhstan.»]. moxnpn.ru. Retrieved from https://moxnpn.ru/kazakhstan/68-rastitelnyj-i-zhivotnyj-mir-kazaxstana.html [in Russian].

11 Khlus, K.N., \& Khlus, L.N. (2016). Fauna Cheshuekrylykh urboekosistemy h. Chernovtsy (Ukraina). [Fauna of Lepidoptera, urban ecosystems, Chernivtsi (Ukraine)]. Ekolohicheskii monitorinh i bioraznoobrazie - Environmental Monitoring and Biodiversity, 1 (11), 140-143 [in Russian].

12 Sushchev, D.V. (2004). Dnevnye Cheshuekrylye na urbanizirovannoi territorii [Daytime Lepidoptera in the urban area]. Izvestiia TRTU - News TRTU, 1, 220-222 [in Russian].

13 Ahroklimaticheskie resursy Karahandinskoi oblasti Kazakhskoi SSR [Agroclimatic resources of the Karaganda region of the Kazakh SSR]. (1976). Leningrad: Hidrometizdat [in Russian].

14 Zhakataeva, B.T., \& Zhuravleva, Z.P. (2010). Atmosfernye zahriazneniia h. Karahandy [Atmospheric pollution of the city of Karaganda]. Vestnik Karahandinskoho universiteta. Seriia Biolohiia. Meditsina. Heohrafiia - Bulletin of the Karaganda State University. Series Biology. Medicine. Geography, 3 (59), $79-84$ [in Russian].

15 Babochki [Batterflies]. butterflies.kz. Retrieved from http://butterflies.kz/ [in Russian].

16 Andreev, A.V. (2002). Otsenka bioraznoobraziia, monitorinh i ekoseti [Assessment of biodiversity, monitoring and econetworks]. Kishinev: BIOTICA [in Russian].

17 Pavlovsky, E.N. (1957). Metody ruchnoho anatomirovaniia nasekomykh [Methods of hand anatomic study of insects]. Moscow: Izdatelstvo AN SSSR [in Russian].

18 Chineri, M. (2002). Babochki [Butterflies]. Moscow: Astrel [in Russian]. 